\title{
A NOTE ON THE PHAISTOS DISK.
}

ON p. 275 of vol. i. of Scripta Minoa Mr. Arthur Evans notes with regard to the woman-hieroglyph on the Phaistos Disk (No. 6 of his sign-catalogue; see Fig. 1) that " the whole aspect of this figure with its exaggerated breadth of waist contrasts strongly with the Minoan and Mycenaean female types.' On p. 25 he says ' still more divergent from all known examples of Minoan dress is that of the woman. It differs not only in its general broad outline ....., but in almost every detail.' This is so, yet this hieroglyph has one close Mycenaean counterpart as a representation of a woman. I refer to the little female figures in gold plate from the Third Shaft-Grave at Mycenae (Schuchhardt, Schliemann, Fig. 182; see Fig. 2), which ąre practically full-face views of the same squat figure which on the Phaistos Disk is represented in profile. The same curious petticoat is shewn, with its peaked edge, and even much the same unadorned shork of hair. ${ }^{1}$ This is perhaps a point worth noticing,

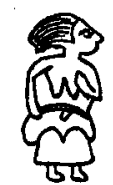

Fig. 1.-WoManHIEROGLYPH.

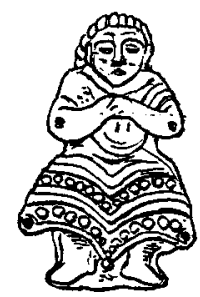

Fig. 2.-Gold Figure of WOMAN.

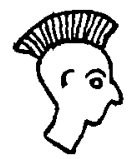

FIG. 3.-MAN's HEADHIEROGLYPH.

as the two representations are very near one another in date, the Disk being 'Middle Minoan III.' and the shaft-grave 'Late Minoan I.'

The crested coif of the man's head-hieroglyph (No. 1 of the Catalogue; see Fig. 3) was at once compared with the crown-like feather headdress of the Philistines as shewn on the monuments of Rameses III. (Fig. 4), and

1 This peculiar style of hairdressing is assigned by Mr. Evans (Seripta Minoa, locc. citt.) to the 'male Shardana ' on the Egyptian monuments. But Dr. W. M. Müller in Asien und Europa, (p. 380, which is quoted by Mr. Evans) thinks that the foreign soldiers with this headdress are of the Tursha tribe, not Shardana; and the Shardana are usually represented as wearing a close-fitting helmet or leather coif surmounted by a crescent and ball. The resemblance of the Tursha headdress to the hair of the woman is, however; as Mr. Evans says, very close. But in the case of these warriors it may not be hair but a feather-headdress like that of the Philistines. 
that of the Cyprian soldier on the ivory casket from Enkomi (Excavations in Cyprus, Fig. 19, Pl. I.). I think that we may see it also on the wellknown fragment of a repoussé silver cup with a siege-scene from Mycenae (Perrot and Chipiez, Hist. de l'Art, vi. p. 774, Fig. 365; see Fig. 5). In this scene the slingers defending the city seem to have curious shocks of short hair starting from their heads. It seems to me much more

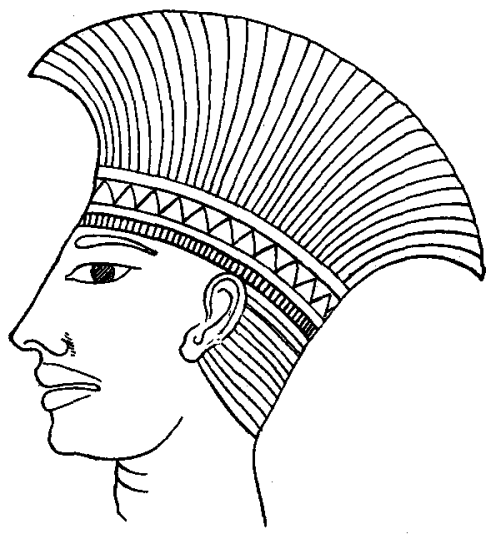

Fig. 4.-A Philistine.

(From B.S.A. viii. p. 185.) probable that what is really intended is a feather headdress like that of the Philistines. The scene on this cup most probably represented an attack (by Cretans or other 'Mycenaeans') on a foreign city, but only a fragment shewing its defenders is left: we do not see any of the attackers. It is quite possible that the city was situated in Lycia or elsewhere on the Asiatic coast, to which this characteristic feather-headdress may be assigned, as we see from Herodotos (vii. 92), who describes the Lycian soldiers of Xerxes

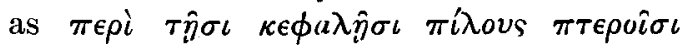
$\pi \epsilon \rho \iota \sigma \tau \epsilon \phi a \nu \omega \mu \epsilon \operatorname{\nu ovs.~It~is,~so~far~as~one~}$ can see, not Minoan Cretan, any more than is the Phaistos Disk, ${ }^{2}$ to which Mr. Evans

has with such great probability assigned a Lycian origin (Scripta Minoa, p. 287). The non-Cretan character of this headdress, coupled with the northern style of their shields, is, as I have pointed out elsewhere, ${ }^{3}$ the chief objection to the acceptance of the view that the Philistines (who were doubtless, as tradition agrees, emigrants from Crete) were descendants of the Minoan Cretans, and not rather of some conquering race (from Lycia?) which had settled in Crete, and were expelled thence.

But if we want the Philistines to be descendants of the Minoans (and their pottery from Tell es-Safi is certainly descended from the typically Cretan pottery of the Third Late Minoan period, which was found at Palaikastro and elsewhere), we must suppose that they had by the twelfth century abandoned their ancient characteristic armour and headgear for that of a neighbouring (and probably conquering) people, with which, as the silver cup seems to shew, Mycenaeans had been at war. This foreign people, who probably lived in Lycia, had relations with Crete at least as far back as the Third Middle Minoan period (about 1700-1600 B.c.), to which period belongs the deposit at Phaistos in which the Disk was found (Scripta Minoa, p. 273).

I append a photograph, Fig. 6 (p. 122), of a very interesting little faience

${ }^{2}$ Mr. Evans's argument (Scripta Minoa, p. 285) to this effect, in opposition to the views of the discoverers of the disk, seems quite conclusive.
3 Proceedings of the Society of Biblical Archaeology, xxxi. p. 234. In this article I have already mentioned the view, given above, which I ho:d as to the silver cup-fragment. 
figure, found in Malta or Gozo some years ago, which undoubtedly represents a warrior of this feather-bearing race, probably at a period not later

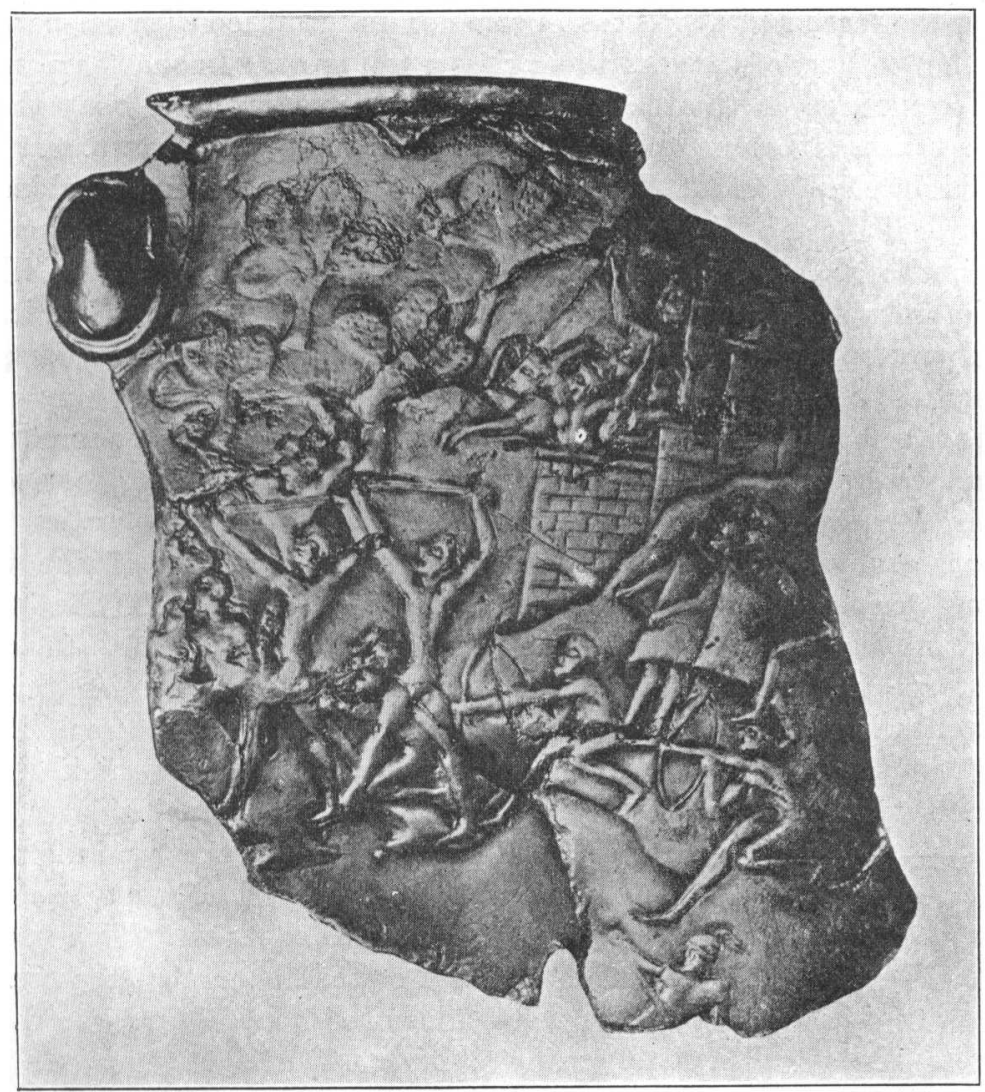

Fig. 5.-Fragment of Silver Cup From Mrcenae.

(From au Electrotype.)

than that of the Enkomi ivory box (? XIIth-XIth cent. B.C.). It is difficult to say from the photograph ( $I$ have not seen the original) whether it is of Egyptian manufacture or not. The fact of its being a caricature points to an Egyptian origin. It is a child's doll, with movable arms and legs (the latter are missing). The grinning face, which admirably caricatures a sea-worn and war-worn visage, is crowned by the feather-headdress, and framed in a band which seems to continue the coif round the chin, coming in front of the enormous ears. The man wears a necklace, and a heavy waist-cloth of hairy animal-skin. The photograph of this figure was sent to me by the late Father Magri, who had recognized its resemblance to the Egyptian representations of the Philistines. So far as I know, it has not hitherto been published; I believe it is in the Malta Museum. 
The latest occurrence of this headdress is in an Assyrian relief of the time of Sennacherib representing Ionians, possibly ambassadors, accompanied by mercenary soldiers of the same race (Fig. 7). ${ }^{4}$ We here see bearded warriors wearing the feathered headdress, in some cases furnished with ear-flaps, while above the feathers of three of them rises a tall crest. In the three instances of its occurrence in this form (see Fig. 7) it is probable that the crest may be taken to belong to the same head as the feather-crown. It was so regarded by Dr. W. M. Müller, who saw in it an interesting combination of the national Lycian Federschmuck with the Greek helmet. ${ }^{5}$ The crested soldiers, who accompany them, may be Assyrians, but this is not likely, as it is improbable that the Assyrians had adopted the crest (which they certainly took over from their Ionian and Carian mereenaries) as early as the time of Sennacherib. It is improbable that they had any western mercenaries before Sennacherib's time (it was he who conquered Cilicia and first came into contact with the Ionians, $v$. L. W. King, Sennacherib and the Ionians, J.H.S. xxx. pp. $327 \mathrm{ff}$.); and the modification of the Assyrian equipment which was carried out in imitation of the western form of armour can hardly have come into vogue till the time of Asshurbanipal. By that time the Assyrians had given up their small round targe in favour of the great shield which we see on this relief associated with the feathered people. On the Siege Cup from Mycenae (Fig. 5), we see that two of the feathered (?) warriors carry shields of much the same type as that of the relief, and like those which later on the

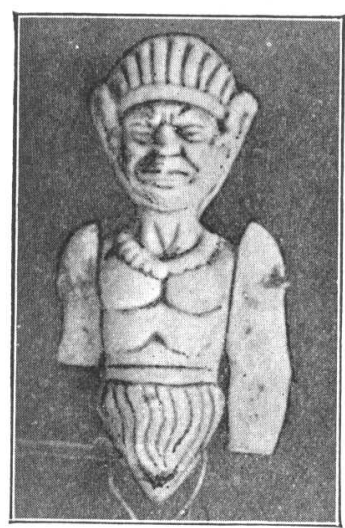

Fig. 6.-Fatence Doli. 'from Malta (p. 120). Assyrians adopted. It is also worth noting that the man lying in the foreground of that scene has a helmet with a long-tailed crest. This is all in favour of the view, stated above, that the Siege Cup represents the defence of some place in Lycia or Caria against a Cretan (?) attack.

The relation of the true helmet-crest to this feather-headdress of Asia Minor is interesting. The Greeks always said that the helmet-crest was of Carian origin. It seems probable enough that the feather-crest, like the 'crown,' was originally a characteristic of the people of the Carian-Lycian region, and was passed on by them to the Greeks. The representation on the Phaistos Disk looks very like a short-cut crest, and we see a true long-tailed crest already in Mycenaean times, on the head of one of the warriors on the golden intaglio seal with a scene of a combat. ${ }^{6}$ The

\footnotetext{
4 Layard, Nineveh, ii. 44.

5 Asien und Europa, p. 362, where the combined headdress is figured. Dr. Miiller's identification of the feather-crown of these Ionian mercenaries with the 'crown,' which in the inscription of Naksh-i-Rustam Darius I.
}

says was worn by the Jonians, is extremely probable. He points out the latest reference to the feather-headdress as worn by the Lycian soldiers of Xerxes in Hdt, vii. 92, mentioned above.

${ }^{6}$ Schuchhardt, Schliemann, Fig. 221. 
curved object above the head of the foremost warrior on the 'Chieftain' Vase from Agia Triada is, however, not a crest rising from a low helmet. It is the upper part of a weapon or staff of command, held in the left

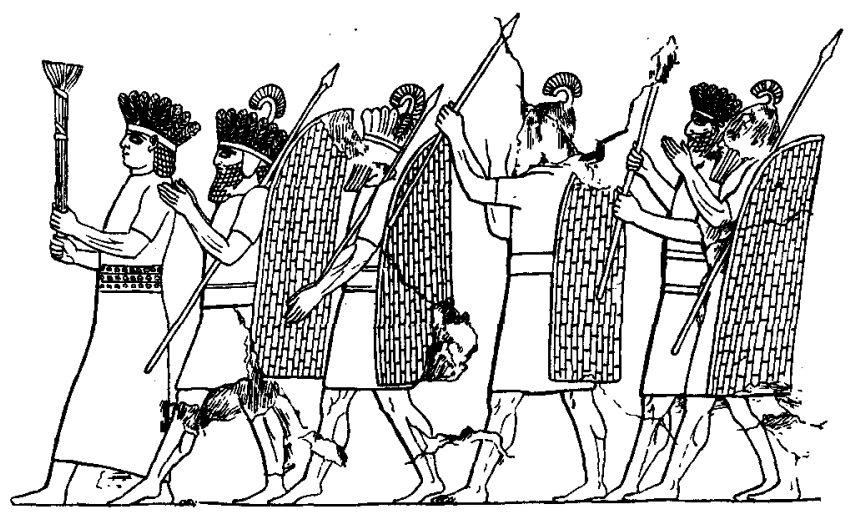

Fig. 7.-Procession of Ionians on Carians:

RELIEF FROM KUYUNJIK.

hand, while the right holds the sword 'at attention.' This warrior wears no helmet : what looks somewhat like one is evidently, on close inspection, his long hair coiled up on the top of his head to be out of the way when fighting.

H. R. HaLL. 